Research Article

\title{
Cyclic Behavior of Confined Cement-Stabilized Rammed Earth Walls
}

\author{
Xinlei Yang $\left(\mathbb{D},{ }^{1,2}\right.$ Hailiang Wang $\mathbb{D},^{2}$ and Ziliang Zhao ${ }^{1}$ \\ ${ }^{1}$ School of Civil Engineering, Tianjin Chengjian University, No. 26, Jinjing Road, Xiqing District, Tianjin 300384, China \\ ${ }^{2}$ Tianjin Key Laboratory of Civil Buildings Protection and Reinforcement, No. 26, Jinjing Road, Xiqing District, \\ Tianjin 300384, China
}

Correspondence should be addressed to Hailiang Wang; whl@tcu.edu.cn

Received 8 April 2018; Revised 30 June 2018; Accepted 16 July 2018; Published 25 September 2018

Academic Editor: Tai Thai

Copyright ( $) 2018$ Xinlei Yang et al. This is an open access article distributed under the Creative Commons Attribution License, which permits unrestricted use, distribution, and reproduction in any medium, provided the original work is properly cited.

\begin{abstract}
Rammed earth is widely utilized in both developed and developing countries due to its low embodied energy and good natural moisture buffering of indoor environments. However, its application in seismic active regions was limited owing to its intrinsically low resistance to dynamic actions. This paper presents the test results of four cement-stabilized rammed earth walls with confining tie-column elements under cyclic loading, aiming at assessing the cyclic behavior of proposed rammed earth walls with confining tie-column elements. The test results revealed that the proposed confining tie-column elements could significantly improve the cyclic behavior of cement-stabilized rammed earth wall, exhibiting good strength and ductility.
\end{abstract}

\section{Introduction}

Rammed earth is an ancient construction technique and has been widely used around the world for millennia [1-3]. Usually, rammed earth walls are monolithic construction and formed by compacting moist raw earth or stabilized earth in progressive layers inside temporary rigid formworks. Rammed earth, a natural and sustainable construction material, has the advantages of low embodied energy, high workability, sound insulation, fire resistance, natural moisture buffering [4], low $\mathrm{CO}_{2}$ emissions, high recyclability, and good thermal inertia [5]. However, there are a few undesirable properties such as low strength, brittle behavior, low durability, and especially low resistance to dynamic actions $[3,6,7]$. Therefore, many rammed earth buildings were severely damaged and even collapsed in earthquakes, such as 2014 Ludian earthquake (M 6.5) in China, 2003 Bam earthquake (M 6.6) in Iran, 2005 Muzaffarabad earthquake (M 7.6) in Pakistan, and 2011 Christchurch Earthquake (M 6.3) in New Zealand [7-10]. These drawbacks had greatly limited the wide application of rammed earth in seismically active regions.

In modern society, excessive exploitation of natural resources causes serious environmental pollution, and the environmental pollution problem becomes a prominent global economic, social, and political issue. Therefore, it will be of immense benefit to minimize the impact on the environment to develop and utilize low embodied energy building materials $[11,12]$. Nowadays, there is a growing interest in using low carbon and low embodied energy materials throughout the world in the context of sustainable building. Among these materials, rammed earth has gradually attracted people's attention and captured the interest of many researchers in recent years due to its low embodied energies and low life cycle cost [13-15].

Generally, rammed earth is a low strength material. In order to utilize this material in new construction in seismic zones, it is necessary to provide adequate additional structural resistance to seismic disturbances, which could be provided by improving material properties and/or suitable structural strengthening solutions.

The material properties of rammed earth could be improved by adding chemical agents such as cement and lime as stabilizing additives [16-19]. The rammed earth improved by adding inorganic additives is often called "stabilized rammed earth" (SRE). There are a lot of research data available for stabilized rammed earth [20-22]. Among stabilizing additives, cement is one of the most commonly 
used stabilizers, and stabilized rammed earth with cement is usually called "cement-stabilized rammed earth" (CSRE). Although cement stabilization could increase construction cost and embodied energy that resulted in environmental impact [23], CSRE gradually gained popularity due to its higher and faster strength gain, durability, and availability with low percentage of cement [24].

Though much research has been focused on the feasibility of applying various stabilizing additives to rammed earth construction to improve the mechanical properties of rammed earth, there are limited investigations that address the issues of enhancing seismic behavior of rammed earth buildings by structural strengthening solutions. Posttensioned reinforcement in lieu of conventional bonded mild steel in rammed earth walls was investigated by Hamilton III et al. [25]. Bamboo splints, as reinforcement, were tested in rammed earth, and the bond resistance through pullout tests was discussed by Tripura and Sharma [26].

In remote mountain areas, it is necessary to construct houses for local inhabitants using surrounding natural materials such as earth and wood due to lacking of good construction materials and high transportation costs. Rammed earth is widely used in remote mountainous areas in western China, especially in the Loess Plateau region, and most of the Loess Plateau region is one of most seismically active areas in China. However, using local soil as a building material in order to reduce costs concerning the construction of low-cost houses is the preferred choice for local residents. Therefore, how to design and construct earthquake-resistant rammed earth buildings is an urgent need in these areas. Due to the fact that the strength of rammed earth is lower, it is necessary to develop simple and effective structural measures to improve the seismic performance of rammed earth structures.

In order to make full use of locally available natural soil resources and minimize environmental impact, an extensive research program has been carried out at Tianjin Chengjian University. The aim of this project is to investigate the cyclic behavior of cement-stabilized rammed earth walls with confining tie-column elements. The proposed confining tiecolumn elements were thin-walled square steel tubes. Prior to this study, there had not been any published data available on thin-walled square steel tubes used in rammed earth. A series of cyclic lateral loading tests of CSRE walls (with and without confining tie-column elements) have been conducted to validate the effectiveness of the proposed structural strengthening solutions.

\section{Experimental Program}

2.1. Materials. In this study, the soil sample was taken from Gongyi County in Henan Province, China, which is located in the East Loess Plateau. The properties of the soil sample were determined per Chinese standard-GB/T 50123 [27] and are listed in Table 1. These properties were complied with the general published recommendations for rammed earth construction [28]. Generally, compaction characteristics of rammed earth are evaluated by two important parameters, i.e., optimum moisture content $(\mathrm{OMC})$ and maximum dry
TABLE 1: Summary of soil properties.

\begin{tabular}{lcc}
\hline Property & Parameters & Percentage value \\
\hline \multirow{4}{*}{ Grain-size } & Gravel fraction & $28 \%$ \\
distribution & Sand fraction & $44 \%$ \\
& Silt fraction & $13 \%$ \\
Atterberg & Clay fraction & $15 \%$ \\
limit & Liquid limit & $27.8 \%$ \\
& Plastic limit & $17.7 \%$ \\
Proctor test & Plastic index & $10.1 \%$ \\
& Optimum moisture content & $16.5 \%$ \\
& Maximum dry density $\left(\mathrm{kg} / \mathrm{m}^{3}\right)$ & 1710 \\
\hline
\end{tabular}

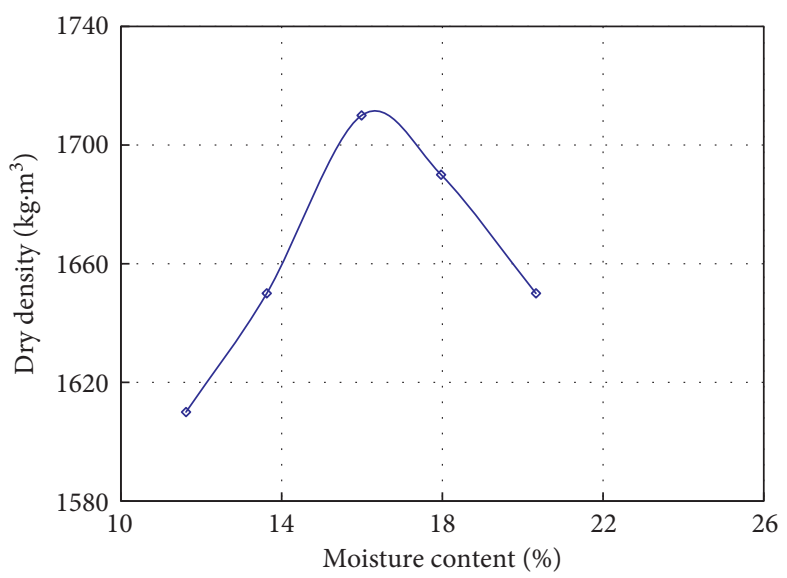

Figure 1: Dry density vs. moisture content at $10 \%$ cement.

density (MDD). Figure 1 shows the dry density-moisture content curve determined by the Standard Proctor tests. It could be seen that the OMC is $16.5 \%$, and MDD is $1710 \mathrm{~kg} / \mathrm{m}^{3}$ for the soil sample.

In consideration of the availability, economy, and ease of construction, Portland cement was the selected stabilizer. Ordinary Portland cement of 42.5-grade conforming to GB 175 [29] was used in the experimental investigations. Generally, as soil stabilizer, the cement content in the range of $6-10 \%$ (by weight) was used for CSRE elements to gain higher strength and durability [17]. In the experimental investigations, $10 \%$ cement by dry mass of soil was used for the production of test specimens. The obtained soil and cement constituents by X-ray diffraction are given in Table 2 . The strength of stabilized rammed earth in the tested specimens varied between 6.3 and $8.5 \mathrm{MPa}$.

In the test specimens, the diameter of corrosion resistant zinc-coated wire which was used as wire ties is $2.6 \mathrm{~mm}$, the confining tie-column elements are thin-walled square steel tubes of Grade Q235 with a wall thickness of $3 \mathrm{~mm}$. Table 3 summarizes the properties of the wire ties, steel tube, and steel beam. For Specimen W-3, the steel tube column was filled with concrete with a target compressive strength of $30 \mathrm{MP}$.

2.2. Description of Test Specimens. The prototype structure was a rectangular one-story rammed earth structure in China, with a plan dimension of $4.8 \mathrm{~m} \times 12.9 \mathrm{~m}$ and a $3.6 \mathrm{~m}$ 
TABle 2: Soil and cement chemical composition (content (\%)).

\begin{tabular}{lcccccccccccc}
\hline Samples & $\mathrm{SiO}_{2}$ & $\mathrm{Al}_{2} \mathrm{O}_{3}$ & $\mathrm{Fe}_{2} \mathrm{O}_{3}$ & $\mathrm{CaO}$ & $\mathrm{Na}_{2} \mathrm{O}$ & $\mathrm{K}_{2} \mathrm{O}$ & $\mathrm{MgO}$ & $\mathrm{TiO}_{2}$ & $\mathrm{P}_{2} \mathrm{O}_{5}$ & $\mathrm{Cl}$ & $\mathrm{SO}_{3}$ & $\mathrm{IL}$ \\
\hline Cement & 21.61 & 5.59 & 3.01 & 58.23 & 0.27 & 1.24 & 4.01 & 0.36 & 0.08 & 0.04 & 3.01 & 2.31 \\
Soil & 50.29 & 12.11 & 4.17 & 9.80 & 1.69 & 2.46 & 2.70 & - & - & - & - & 1.54 \\
\hline
\end{tabular}

TABLE 3: Mechanical properties of wire ties, steel tube, and steel beam.

\begin{tabular}{lccccc}
\hline Material & $t(\mathrm{~mm})$ & $f_{\mathrm{y}}(\mathrm{MPa})$ & $f_{\mathrm{u}}(\mathrm{MPa})$ & $E_{\mathrm{s}}(\mathrm{GPa})$ & $\begin{array}{c}\text { Elongation } \\
(\%)\end{array}$ \\
\hline D2.6 & - & 352 & 435 & 202 & 15.4 \\
Steel tube & 3 & 308 & 406 & 195 & 26.5 \\
Steel beam & 5 & 311 & 397 & 193 & 24.3 \\
\hline
\end{tabular}

story height. The transverse walls in the building were chosen as the object of study. Due to the experimental space constraints, the prototype wall was reduced to a $1 / 3$-scale model. In order to gain a deep understanding of effects of the confining tie-column elements and wire ties on the cyclic behavior of CSRE walls, five specimens were constructed.

Structural characteristics of each tested specimen are briefly summarized in Table 4 and shown in Figure 2. Specimen Q-1 was a traditional CSRE wall without confining tie-column elements, which was used as the control specimen, as shown in Figure 2(a). Specimen SF was used to determinate the strength of steel frame, which consists of two hollow thinwalled square steel tube columns and one $8 \#$ channel steel beam, as shown in Figure 2(b). The other three specimens were CSRE walls with confining tie-column elements. For Specimen W-1, the CSRE wall was confined by two hollow thin-walled square steel tube tie-columns and two wire ties, and the location of wire ties is shown in Figure 2(c). For Specimen W-2, the CSRE wall was confined by two hollow thin-walled square steel tube confining tie-column elements and one 8\# channel steel confining bond-beam, as shown in Figure 2(d). Specimen W-3 was exactly the same in all respects to that of Specimen W-1 except that the thin-walled square steel tube tie-columns were filled with concrete, and the detailing of this specimen is shown in Figure 2(e). The thickness of all the wall specimens is $200 \mathrm{~mm}$.

Dry mixing of soil with $10 \%$ cement (by mass of dry soil) was carried out before mixing with an optimum quantity of water equal to $19 \%$. The soil-cement mixture, prepared with some moisture, was placed in layers of about $350 \mathrm{~mm}$ and then compacted with a D9 pneumatic rammer to around $55 \%$ of its original height. Compaction in the corners was accomplished using a steel rammer. Once the soil-cement mixture was compacted well, the next lift would be followed. Each wall specimen consisted of seven layers of rammed earth, and the height of each layer was about $200 \mathrm{~mm}$. Figure 3 presents photographs of the construction site. The construction method of earth walls used herein is similar to that used in rural areas in China. The main difference is the use of pneumatic tools.

2.3. Test Setup and Instrumentation. A servo-hydraulic actuator with $150 \mathrm{kN}$ maximum load and a $\pm 250 \mathrm{~mm}$
TABLe 4: Summary of Structural characteristics of the tested specimens.

\begin{tabular}{|c|c|c|}
\hline Specimen & Structural characteristics & Remarks \\
\hline Q-1 & Without confining tie-column elements & $\begin{array}{l}\text { Control } \\
\text { specimen }\end{array}$ \\
\hline SF & $\begin{array}{l}\text { Hollow thin-walled square steel tube } \\
\text { columns + channel steel beam }\end{array}$ & \\
\hline $\mathrm{W}-1$ & $\begin{array}{l}\text { Hollow thin-walled square steel tube } \\
\text { confining tie-column elements }+2 \text { wire ties }\end{array}$ & \\
\hline $\mathrm{W}-2$ & $\begin{array}{l}\text { Hollow thin-walled square steel tube } \\
\text { confining tie-column elements }+1 \text { wire ties } \\
+8 \# \text { channel steel confining bond-beam }\end{array}$ & \\
\hline $\mathrm{W}-3$ & $\begin{array}{l}\text { Hollow concrete filled thin-walled square } \\
\text { steel tube confining tie-column elements } \\
\qquad+2 \text { wire ties }\end{array}$ & \\
\hline
\end{tabular}

displacement range was used to apply a quasi-static lateral loading to $1200 \mathrm{~mm}$ in height in two opposite directions. A hydraulic jack was used to carry out a constant axial load to the top of the walls to simulate gravity actions. Specimen SF was subjected to horizontal reversed cyclic loading without vertical load. The loading devices and the test setup are shown in Figures 4 and 5, respectively.

For each test wall, a total of five displacement sensors were used to record the displacements at different loading stages, as shown in Figure 6. The relative displacement between the ground beam and the strong floor was measured by number $D_{0}$. The relative displacement between the ground beam and the wall was measured by number $D_{3}$. Lateral displacement of the tested walls was measured by numbers $D_{1}$ and $D_{2}$. Diagonal strain of the wall was recorded by numbers $D_{4}$ and $D_{5}$, which were positioned in diagonal direction.

Electrical resistance strain gauges were placed at critical sections of beams and columns, as well as on the wire ties. The measured data of load, displacements, and strains were continually recorded by a data acquisition system.

2.4. Test Procedure and Loading Characteristics. A constant axial load of $26.43 \mathrm{kN}$ simulating gravity actions was applied to the wall and maintained constant throughout each test. After application of the axial load to the top of the steel beam, low rate of lateral cyclic loading with increasing amplitudes that simulated lateral earthquake loading was applied to a height of $1200 \mathrm{~mm}$. The test walls were loaded in a displacement (drift) controlled mode at a constant rate of $0.2 \mathrm{~mm} / \mathrm{s}$, and two fully reversed cycles were applied at each drift. The selected drift was intended to cause inelastic deformations of the wall subjected to earthquake action. The drift was defined as follows: $\operatorname{drift}=\Delta / H$. Here $H$ $(H=1200 \mathrm{~mm})$ was the height of the centerline of the loading measured from the fixed ends of the specimens and $\Delta$ was the lateral displacement of the specimens. 


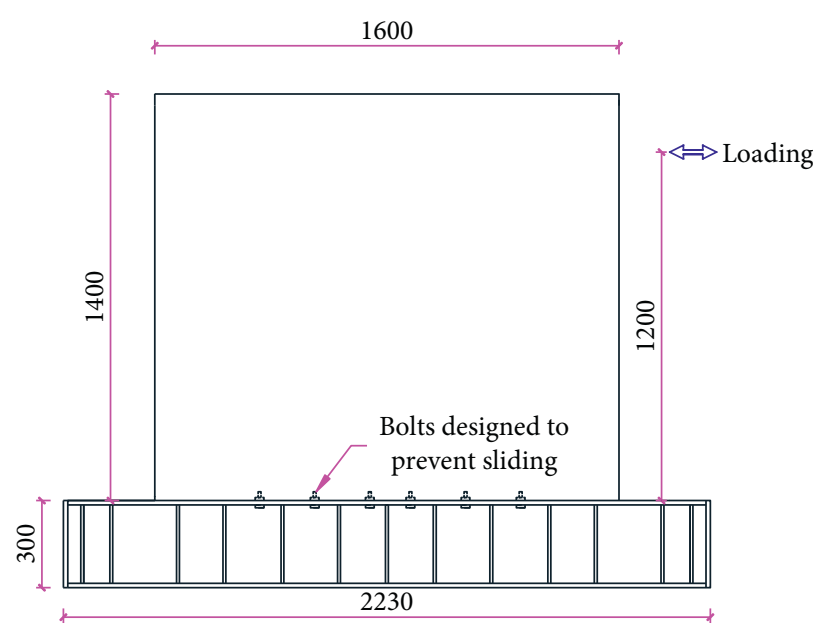

(a)

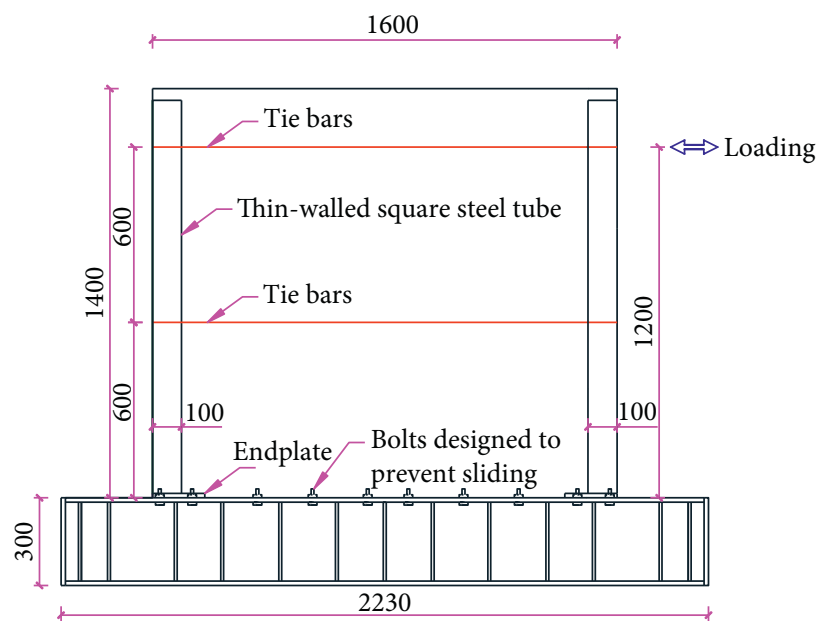

(c)

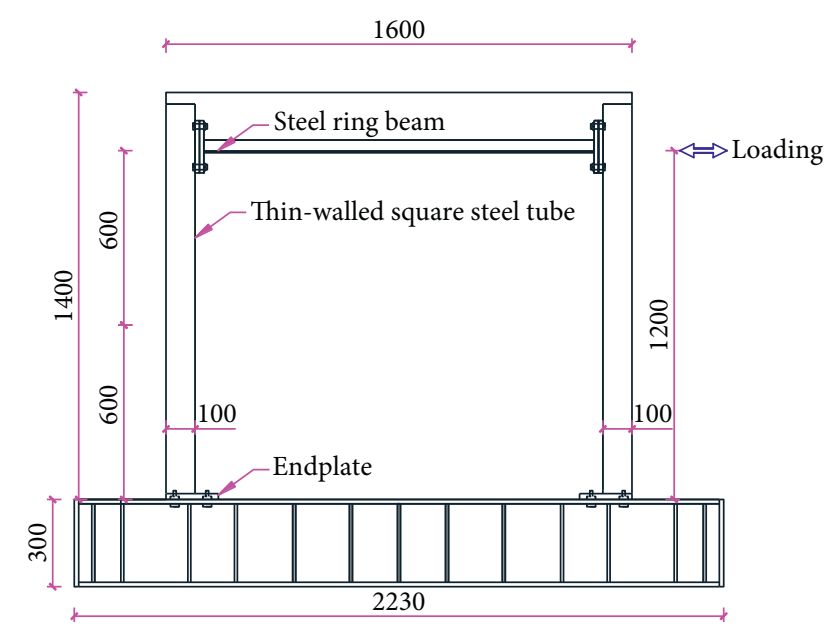

(b)

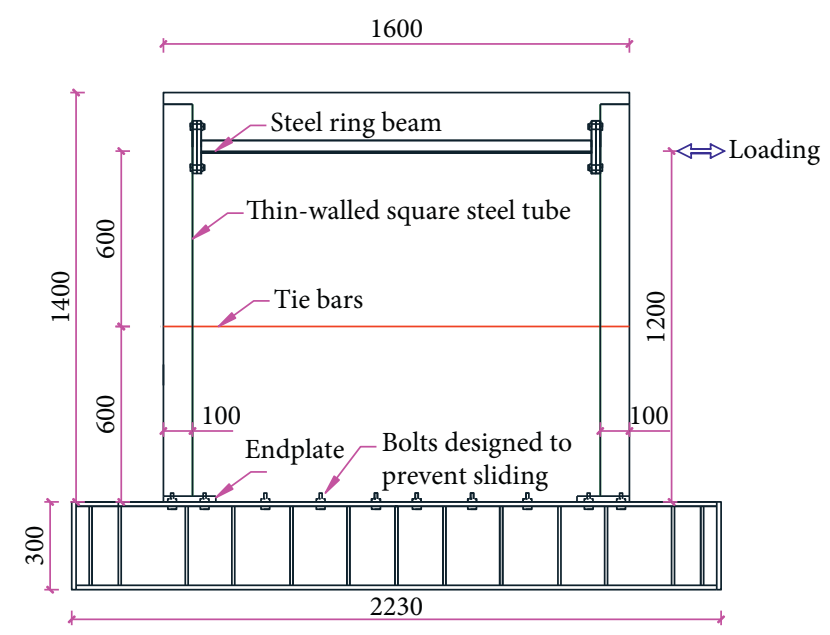

(d)

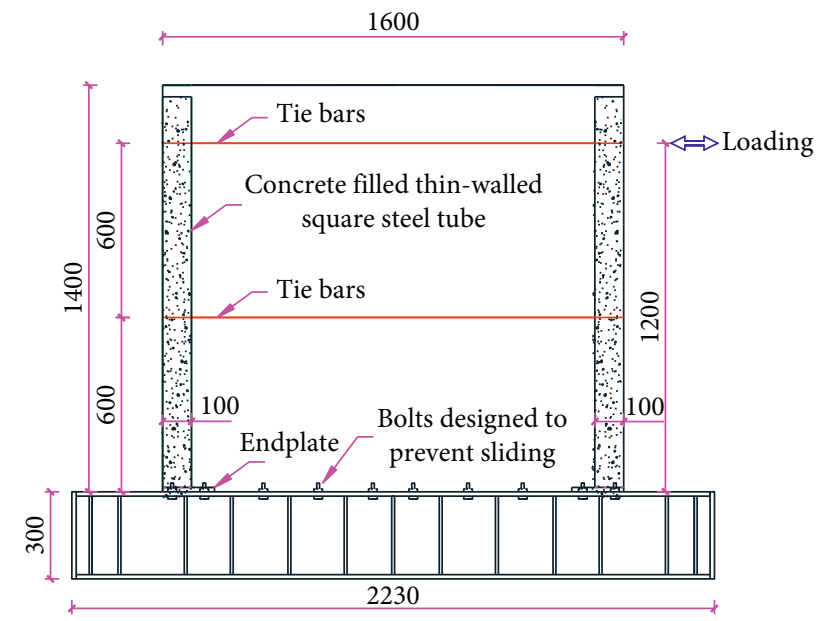

(e)

FIgURE 2: Geometry and details of the tested specimens. Note: CSRE is not shown for clarity. (a) Specimen Q-1 (without confining tiecolumn elements). (b) Specimen SF (steel frame only). (c) Specimen W-1. (d) Specimen W-2. (e) Specimen W-3.

Each test was initiated at interval step of $0.1 \%$ drift ratio until $0.8 \%$. In the range of $0.8 \% \sim 2 \%$ drift, the specimen was cycled at interval steps of $0.2 \%$. In the range of $2 \% \sim 4 \%$ drift, the specimen was cycled at interval steps of $0.4 \%$. When the drift reached $4 \%$, interval steps of $0.8 \%$ drift were imposed to the specimens until failure or instability. The lateral cyclic loading protocol is shown in Figure 7. 


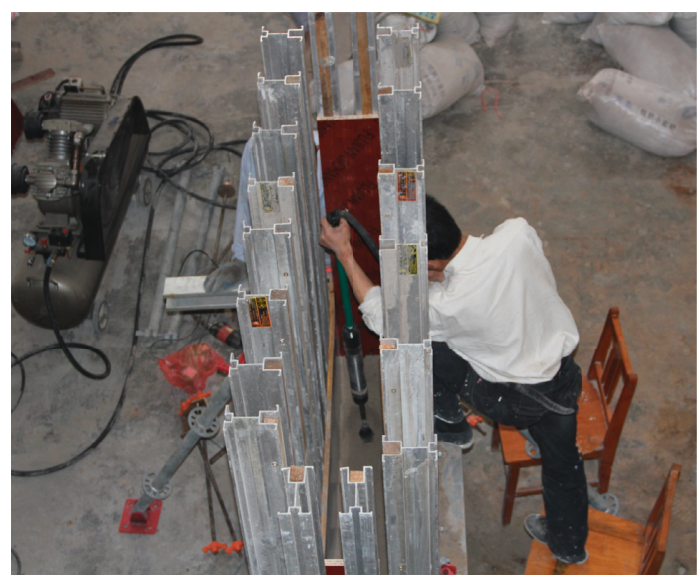

(a)

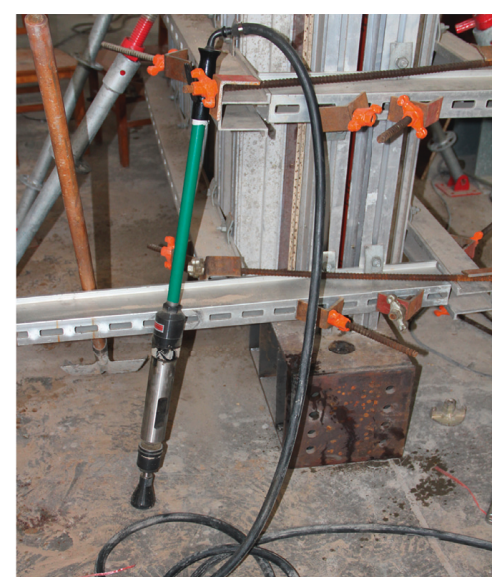

(b)

FIgURE 3: Moulds and pneumatic rammer used for specimen construction. (a) Supports and moulds. (b) D9 pneumatic rammer.

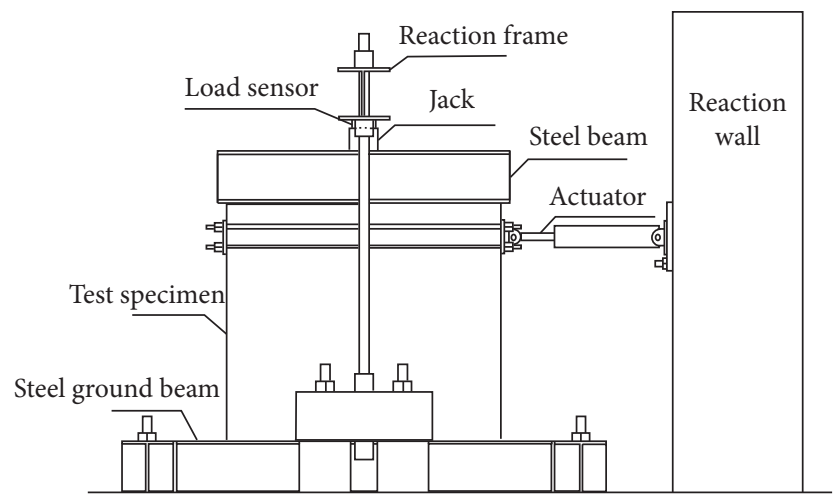

Figure 4: The schematic drawing of loading devices.

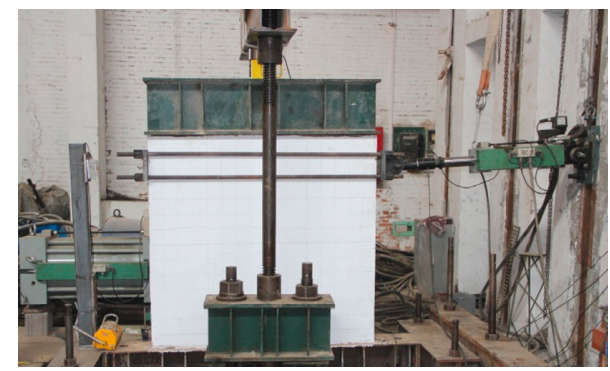

Figure 5: The picture of test setup.

\section{Experimental Results}

3.1. Damage Observations Failure Pattern. The final failure patterns of each specimen are illustrated in Figure 8. Similar failure patterns were observed in the tested specimens while increasing displacement, as described below:

Specimen Q-1: the damage started to occur at a drift of approximately $0.2 \%$, and the first horizontal crack was observed at a distance of about $230 \mathrm{~mm}$ from the top of the ground beam. Under cyclic loading, the horizontal crack grew gradually in width and propagated through the wall when the drift was $0.3 \%$. At a drift of $0.6 \%$, Specimen Q-1 was separated into two parts by a wide

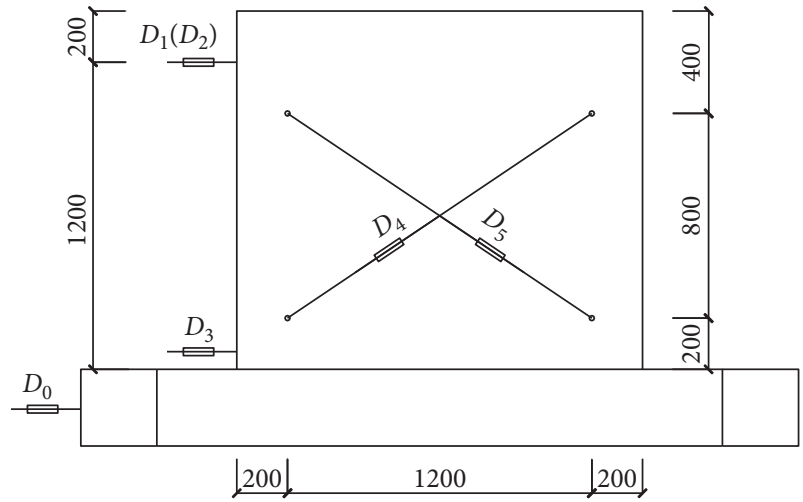

— LVDT

FIgURE 6: Measurement layout of instrumentation.

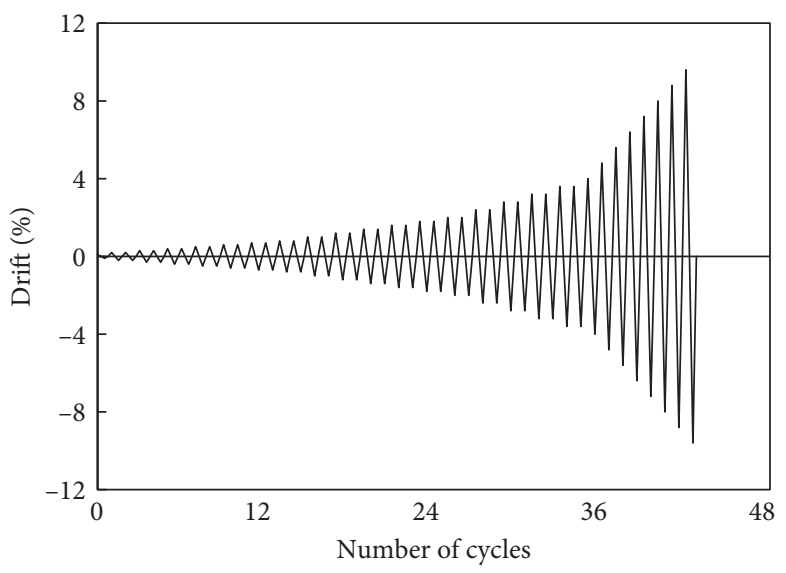

FIgURE 7: Loading history.

horizontal crack, and the relative slipping between the two parts was observed. The ultimate failure mode is shown in Figure 8(a).

Specimen SF: the weld cracks at the surface of column base commenced at a drift of $6.4 \%$ and grew in size as 


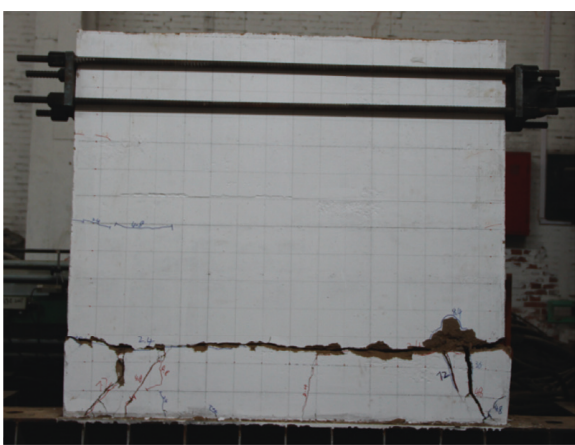

(a)

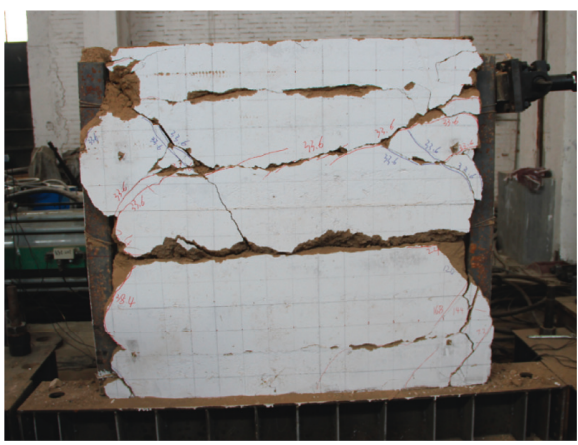

(c)

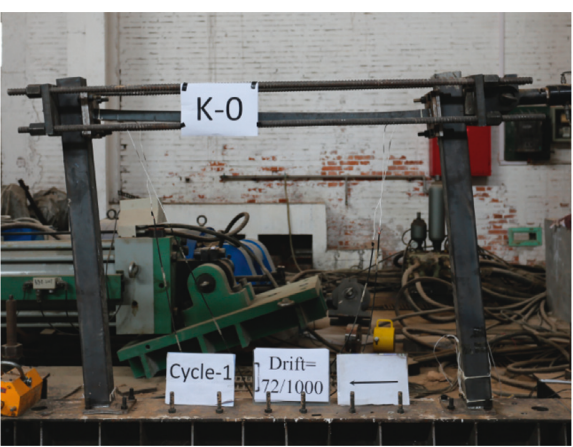

(b)

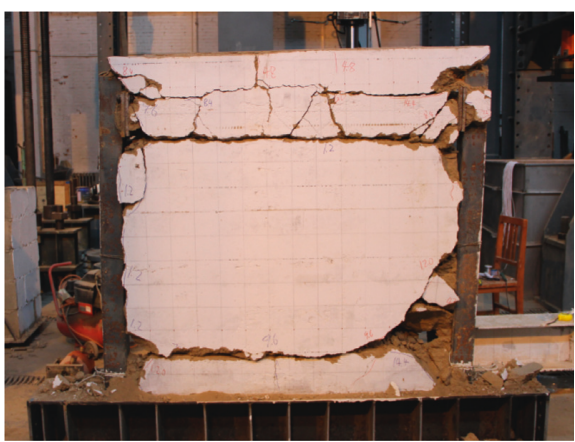

(d)

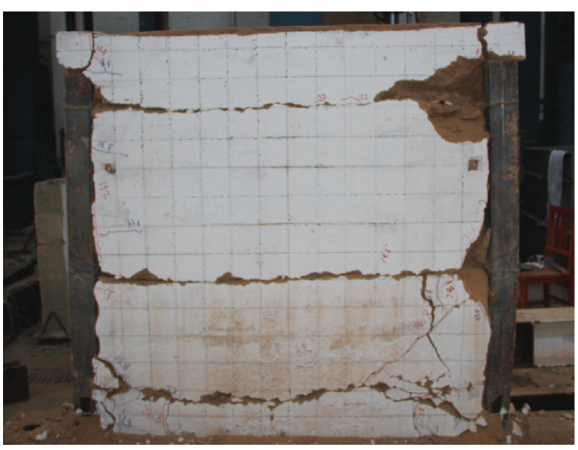

(e)

Figure 8: Failure patterns of tested specimens. (a) Specimen Q-1. (b) Specimen SF. (c) Specimen W-1. (d) Specimen W-2. (e) Specimen W-3.

the drift increased, which caused the yield cracking of column base surface, as seen in Figure 8(b).

Specimen $W-1$ : at a drift of $0.2 \%$, the first horizontal crack initiated in the middle of the wall, where a wire tie was placed corresponding to cracking load of $17.39 \mathrm{kN}$. Compared with the control specimen, cracks in Specimen $\mathrm{W}-1$ propagated more slowly, attributing to the contribution of confining tie-column elements. An inclined crack appeared at a drift of $1 \%$. Diagonally inclined and intersected cracks were observed at a drift 2.8\%. At a drift of $4 \%$, Specimen W-1 was separated into multiple parts by horizontal and inclined cracks. The final failure pattern of Specimen W-1 is shown in Figure 8(c).

Specimen $W-2$ : at a drift ratio of $0.1 \%$, a long horizontal crack appeared under the channel steel confining bondbeam, due to the fact that the rammed earth under the channel steel confining bond-beam was not compacted well since the space used for construction was too small. A new horizontal crack appeared in the lower part of the wall at a drift of $0.6 \%$. The inclined crack began to appear at a drift of $1 \%$. The bearing capacity reached its capacity at a drift $2.8 \%$. The crushing of rammed earth was observed at the corners of the wall in subsequent cycles. The final failure pattern of Specimen W-2 is shown in Figure $8(\mathrm{~d})$.

Specimen $W-3$ : at a drift of $0.2 \%$, the first horizontal crack was observed at a distance of about $600 \mathrm{~mm}$ from the top of the ground beam. The second horizontal crack appeared at the height of loading position at a drift of $0.6 \%$. The horizontal cracks gradually propagated with the increase of drift. When the drift reached $3.6 \%$, the rammed earth clump dropped near the confining tie-column elements. The failure mode of Specimen W-3 is shown in Figure 8(e). 
Under lateral cyclic loading, the damage of the rammed earth wall specimens was mainly distributed near layers. The failure mode of each rammed earth wall was controlled by horizontal cracks caused by horizontal shear, illustrating that the rammed earth layers were vulnerable regions of walls.

\subsection{Hysteretic Behavior and Response Envelopes.} Hysteresis curves are often used to assess the seismic behavior of tested specimens subjected to cyclic loading, in terms of the energy dissipation capacity, the ductility performance, strength deterioration, and stiffness degradation. The hysteretic curves of each specimen are presented in Figure 9.

Generally, the hysteretic characteristic of each specimen was basically similar at initial loading phase. Before the cracking load, the area enclosed by the hysteretic curves was nearly identical with a straight line, and residual deformation was almost nothing, indicating that all the specimens still kept in elastic stage. After cracking load, the slope of hysteretic curves started to decline, and the hysteretic loops became a spindle with increasing lateral displacement. It could be found that the areas of hysteretic loops became larger gradually with stiffness degradation, showing that the specimens entered the elastoplastic stage.

The hysteretic loops of Specimen Q-1 was much smaller than those of other three walls with confining tie-column elements, indicating that the proposed strengthening measures made a significant contribution to the bearing and deformation capacity.

Figure 10 gives the comparison of the skeleton curves of all the test specimens. From these skeleton curves, it could be seen that the skeleton curve of each specimen was almost identical to a straight line and the force-displacement was approximately linear during the initial loading stage. As the drift increased, the cracks appeared and gradually propagated, and each specimen showed an apparent stiffness degradation. After the yield point, the stiffness degradation was more obvious. After reaching the peak load, the bearing capacity of the walls with confining tie-column elements decreased slowly, and the skeleton curves exhibited good ductility without notable strength drops until the end of testing.

Comparing the skeleton curves, it could be seen that the bearing capacity and ductility of rammed earth was significantly improved by confining tie-column elements. At the drift of $0.8 \%$, the bearing capacity of Specimen Q-1 is $15.1 \mathrm{kN}$, which was increased by $253 \%, 328 \%$, and $304 \%$, when compared with the bearing capacity of Specimens $\mathrm{W}-1, \mathrm{~W}-2$, and $\mathrm{W}-3$, respectively. The increase of the bearing capacity was attributed to the confining tie-column elements.

The deformation capacity of the rammed earth wall was significantly improved by the confining tie-column elements. At the drift of $0.8 \%$, the bearing capacity of Specimen Q-1 dropped to 74 percent of its peak load, while the bearing capacity of Specimens W-1, W-2, and W-3 could still hold 85 percent of its peak load at a drift of $4 \%$, respectively.
3.3. Displacement Ductility and Deformability. Displacement ductility is one of the most desirable characteristics of structures, which enables the chosen level of ultimate resistance to be maintained over a large displacement range without a significant loss of load-carrying capacity. The displacement ductility is defined as the ratio between the ultimate and yield displacements. The yield displacement, $\Delta_{\mathrm{y}}$, was determined according to the criteria for equivalent elastoplastic energy absorption used by Park [30], as shown in Figure 11. The ultimate displacement, $\Delta_{\mathrm{u}}$, was determined as the displacement corresponding to a $15 \%$ drop of the peak load. Displacement ductility of the five-wall specimens is listed in Table 5.

The average displacement ductility factor of Specimens $\mathrm{W}-1, \mathrm{~W}-2$, and $\mathrm{W}-3$ is $59.28 \%, 25.89 \%$, and $142.88 \%$ higher than that of Specimen Q-1, respectively; the average ultimate displacement of Specimens W-1, W-2, and W-3 is 540\%, $589 \%$, and $491 \%$ higher than that of Specimen Q-1, respectively. This indicates that the confining tie-column elements could significantly improve the deformation capacity of the rammed earth walls, and the three walls with confining tie-column elements behaved in a ductile manner. Compared with the control specimen, Q-1, the bearing capacity of three specimens with confining tie-column elements was increased by $280 \% \sim 425 \%$, which indicated that the effect of confining tie-column elements was significant.

3.4. Stiffness Degradation. Stiffness degradation is often used as an indicator to describe the stiffness change when a test specimen is subjected to cyclic loading. In this paper, the secant stiffness was taken to assess the stiffness degradation during the test and was computed for each loading cycle at each drift level. The secant stiffness was calculated using a straight line between the maximum load and the corresponding displacement points for the positive and negative directions in a load cycle, as shown in Figure 12. The comparison of stiffness degradation for all specimens is shown in Figure 13.

The stiffness degradation trend of the rammed earth walls with confining tie-column elements was very similar to that of the control specimen. The stiffness of each specimen continuously decreased as the story drift increased. The confined walls had a lower rate of stiffness degradation compared with the control specimen, which was attributed to the restriction from the confining tie-column elements and the confining bond-beam (wire ties). Stiffness degraded rapidly before the drift of $1 \%$ for all specimens, which was probably because most rammed earth cracking occurred in this stage.

The secant stiffness of three confined specimens was $0.41 \sim 0.89$ times higher than that of Specimen Q- 1 at the drift of $0.2 \%$; however, the former was 2.76 times $\sim 3.11$ times greater than the latter, showing that the contribution of the confining tie-column elements to the secant stiffness was significant, especially when the drift was large.

3.5. Energy Dissipation Capacity. The ability of a structure to survive during an earthquake depends a large extent on its 


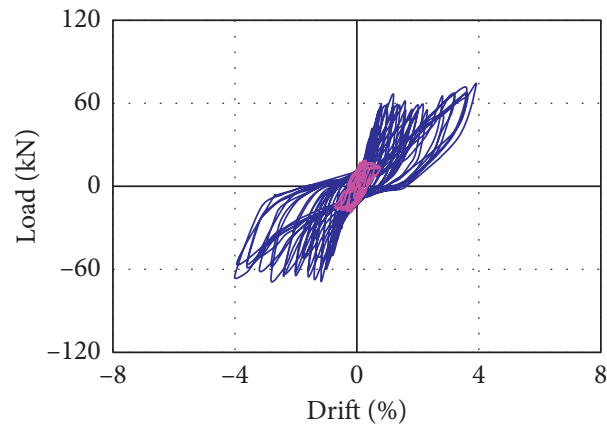

- W-1 --- Q-1

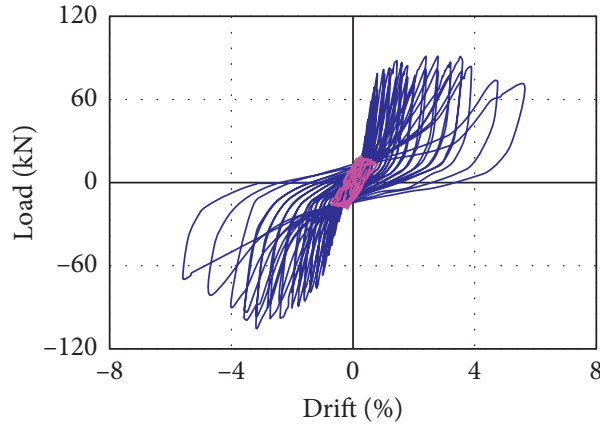

W-2

Q-1

(a)

(b)

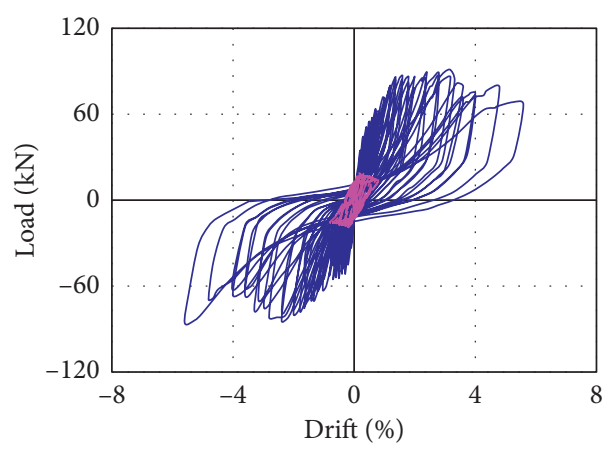

- W-3

$---\mathrm{Q}-1$

(c)

FIGURE 9: Hysteresis curves for the tested specimens. (a) Specimens W-1 and Q-1. (b) Specimens W-2 and Q-1. (c) Specimens W-3 and Q-1.

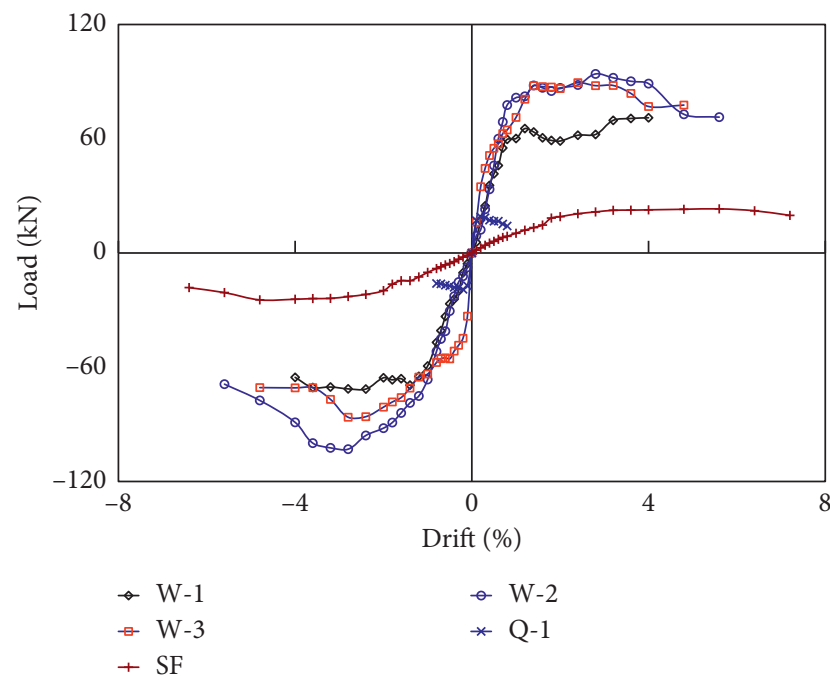

Figure 10: Skeleton curves.

ability to dissipate the input energy. The good energy dissipation capacity indicates the capacity of the structure to perform satisfactorily in the inelastic range. The amount of cumulative energy dissipation is plotted as a function of the drift in Figure 14. All the specimens exhibited a similar pattern of energy dissipation, namely, the energy dissipation

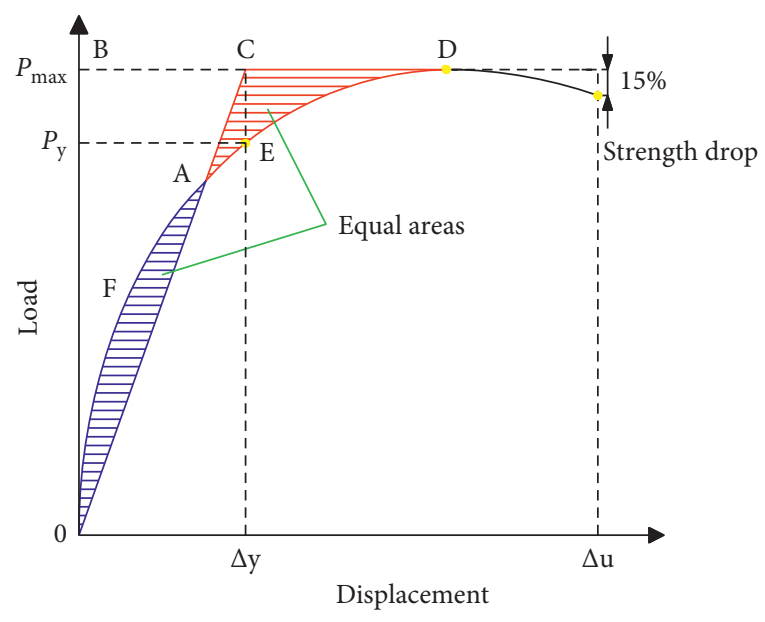

Figure 11: Method used to define the yield and ultimate displacement.

kept on increasing as the drift level increased. The energy dissipation capacity of the confined rammed earth walls was obviously higher than that of Specimen SF at the same drift level, and this showed that the energy dissipation capacity of the confined rammed earth walls mainly depends on the rammed earth rather than the confining tie-column elements. In contrast, there was no obvious difference in the 
TABLE 5: Displacement ductility values of tested specimens.

\begin{tabular}{lcccccccc}
\hline Specimens & Direction & $P_{\mathrm{y}}(\mathrm{kN})$ & $\Delta_{\mathrm{y}}(\mathrm{mm})$ & $P_{\max }(\mathrm{kN})$ & $\Delta_{\max }(\mathrm{mm})$ & $P_{\mathrm{u}}(\mathrm{kN})$ & $\Delta_{\mathrm{u}}(\mathrm{mm})$ & $\mu$ \\
\hline \multirow{2}{*}{ Q-1 } & POS & 16.52 & 1.33 & 18.45 & 3.63 & 15.68 & 7.42 & 5.58 \\
& NEG & 18.45 & 1.35 & 19.04 & 2.42 & 16.18 & 7.46 & 5.53 \\
W-1 & POS & 59.68 & 6.05 & 71.00 & 48.00 & 60.35 & 48.00 \\
& NEG & 59.35 & 4.85 & 71.46 & 30.82 & 60.74 & 47.28 & 9.93 \\
W-2 & POS & 82.02 & 7.32 & 94.03 & 33.16 & 79.93 & 53.28 & 7.28 \\
& NEG & 80.43 & 7.38 & 103.03 & 33.62 & 87.58 & 49.19 & 6.67 \\
W-3 & POS & 63.07 & 4.83 & 89.44 & 28.70 & 76.02 & 47.78 & 9.89 \\
& NEG & 56.51 & 2.45 & 86.24 & 33.83 & 73.30 & 41.83 & 17.07 \\
\hline
\end{tabular}

POS: positive direction; NOG: negative direction; $P_{\mathrm{y}}$ : yield load, $\Delta_{\mathrm{y}}$ : displacement corresponding to the yield load; $P_{\max }$ : peak load, $\Delta_{\max }$ : displacement corresponding to the peak load; $\Delta_{\mathrm{u}}$ : determined as corresponding to a $15 \%$ drop of the peak load; $P_{\mathrm{u}}$ : load corresponding to $\Delta_{\mathrm{u}}$.

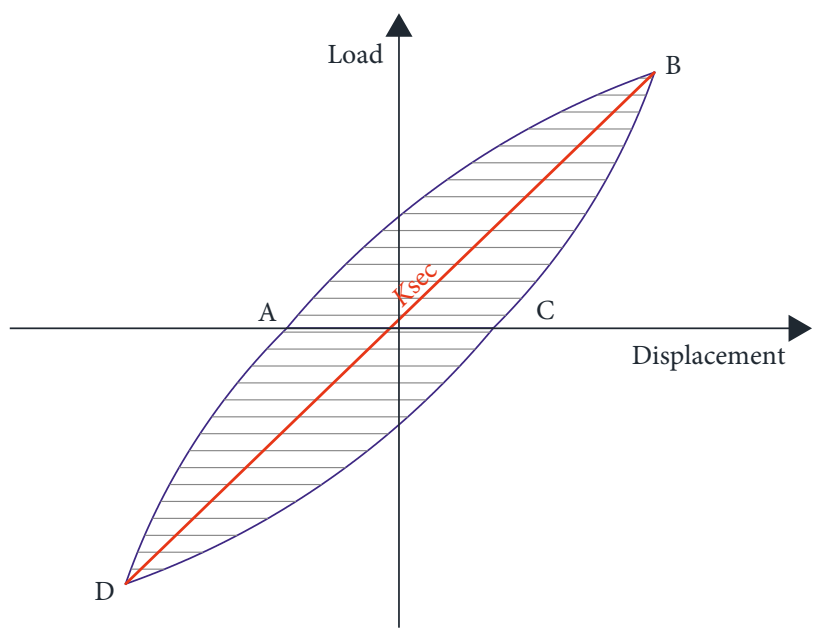

FIGURE 12: Representation of energy dissipated and secant stiffness.

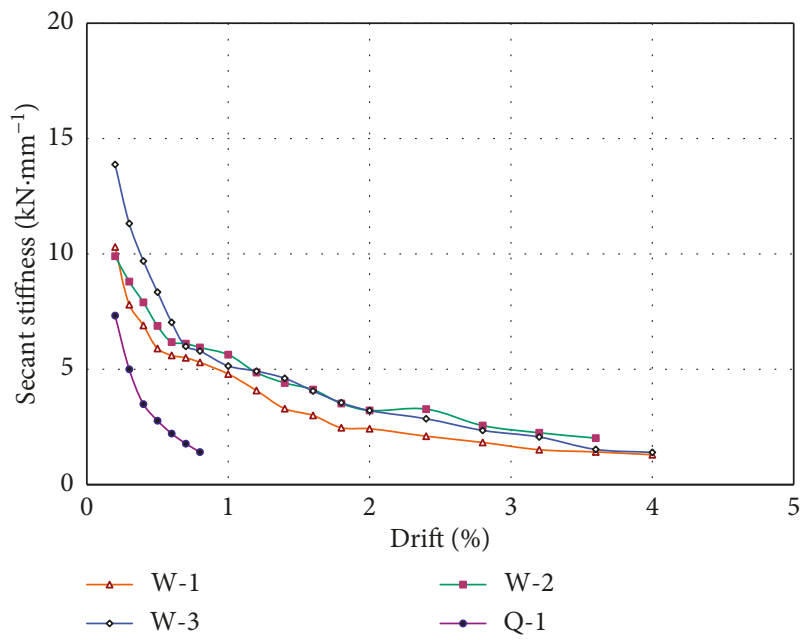

FIgure 13: Stiffness degradation of the tested specimens.

energy dissipation capacity between Specimens W-1 and $\mathrm{W}-2$, showing that using a wire tie instead of a channel steel tie beam had little influence on the energy dissipation capacity of the confined rammed earth. No significant differences were observed in the energy dissipation capacity between Specimen W-1 and W-3 unless the drift was more than about $3 \%$, which showed that the concrete core did not have a significant impact on the energy dissipation capacity.

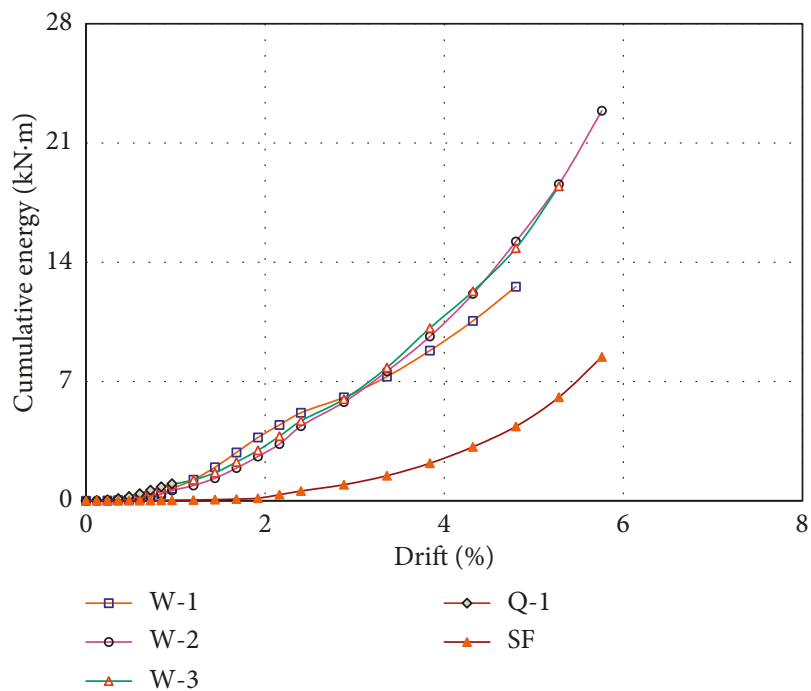

FIGURE 14: Energy dissipation.

\section{Discussion of Influence of Confining Elements on Bearing Capacity}

A comparison of bearing capacity of specimens at different drifts is presented in Figure 15. "Q-1+SF" denotes the summation of the bearing capacity of Specimens SF and Q-1 at the specific drift. Owing to the fact that the test of Specimen Q-1 was terminated at a drift ratio of $0.8 \%$, it is assumed that the subsequent bearing capacity remains constant.

As can be seen from Figure 15, there is little difference between the bearing capacity of Specimens $\mathrm{W}-1, \mathrm{~W}-2$, and "Q-1 + SF" when the drift is below $0.3 \%$, which showed that the combined action of rammed earth walls and confining tie-column elements is weak. However, the bearing capacity of Specimen W-3 is about 1.1 times larger than "Q-1 + SF" at a drift of $0.3 \%$, and this could be due to the fact that the hollow thin-walled square steel tube confining tie-column elements were filled with concrete in Specimen W-3. In general, the combined action of the rammed earth walls and confining tie-column elements on the bearing capacity of rammed earth walls is not significant at the initial stage of loading. As the story drift increases, the effect of the confining tie-column elements on the bearing capacity becomes more obvious. 

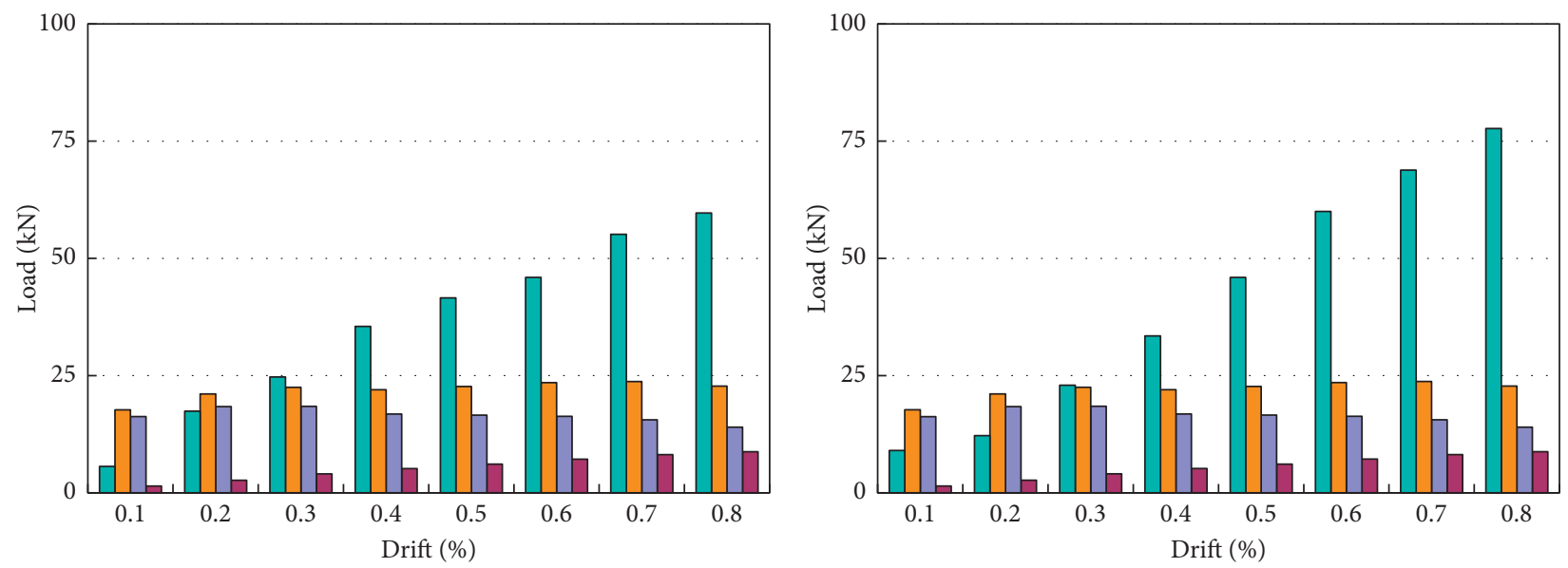

$\square$ SF
$\square$ Q-1
$\square$ SF + Q-1
$\square$ W-1

SF

$\square$ Q-1

$\square \mathrm{SF}+\mathrm{Q}-1$

$\square \mathrm{W}-2$

(a)

(b)

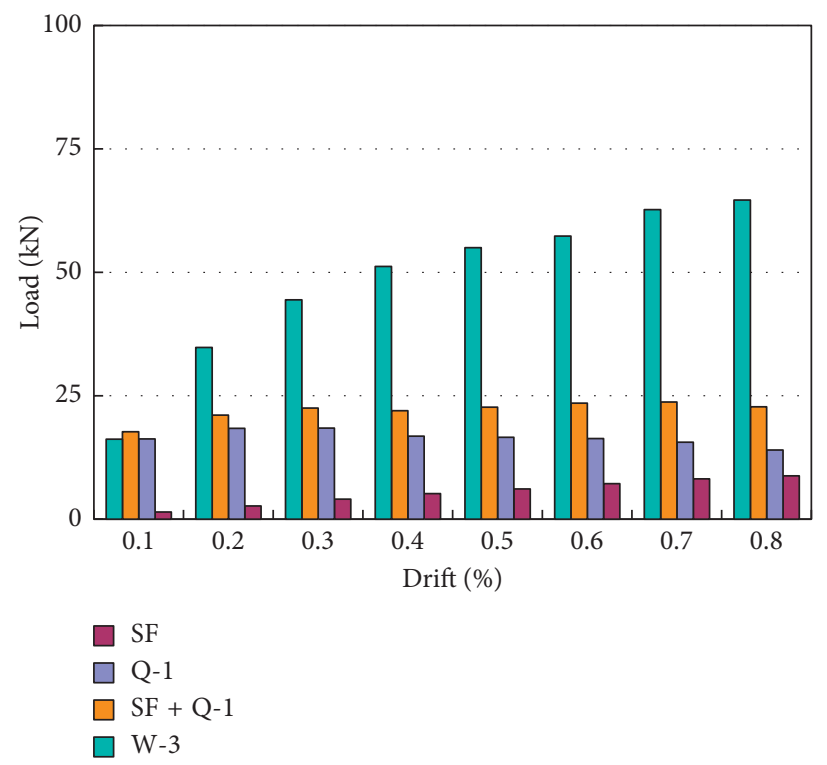

(c)

Figure 15: Comparison of load-bearing capacity at some given drift. (a) Comparison between W-1 and Q-1. (b) Comparison between W-2 and Q-1. (c) Comparison between W-3 and Q-1.

\section{Conclusions}

Based on the quasi-static test of four rammed earth walls, the following conclusions could be drawn:

(1) Under lateral cyclic loading, the failure mode of each rammed earth wall was controlled by horizontal cracks caused by horizontal shear, indicating that the rammed earth layers were vulnerable regions of walls.

(2) Compared with the control specimen, the rammed earth walls with confining tie-column elements exhibited better hysteretic behavior, indicating that the proposed strengthening measures had a significant contribution to the bearing and deformation capacity.
(3) The energy dissipation capacity of the confined rammed earth walls mainly depends on the rammed earth rather than the confining tie-column elements.

(4) The contribution of the combined action of the rammed earth walls and confining tie-column elements to the bearing capacity becomes more significant as the drift increases.

\section{Data Availability}

All data generated or analysed during this study are included in the submitted manuscript. Raw experimental data and 
experimental photographs could be downloaded from https://pan.baidu.com/s/15-Tt3Sl5x1jswWeDFsKqXA.

\section{Conflicts of Interest}

The authors declare that there are no conflicts of interest regarding the publication of this paper.

\section{Acknowledgments}

This work was supported by the Ministry of Science and Technology of the People's Republic of China (Grant No. 2015BAL03B02) and Tianjin Science and Technology Commission (Grant No. 17ZXCXSF00040).

\section{References}

[1] V. Maniatidis and P. Walker, "Structural capacity of rammed earth in compression," Journal of Materials in Civil Engineering, vol. 20, no. 3, pp. 230-238, 2008.

[2] D. D. Tripura and K. D. Singh, "Behavior of cement-stabilized rammed earth circular column under axial loading," Materials and Structures, vol. 49, no. 1-2, pp. 371-382, 2016.

[3] Q. B. Bui, J. C. Morel, B. V. V. Reddy, and W. Ghayad, "Durability of rammed earth walls exposed for 20 years to natural weathering," Building and Environment, vol. 44, no. 5, pp. 912-919, 2009.

[4] Q. B. Bui, J. C. Morel, S. Hans, and P. Walker, "Effect of moisture content on the mechanical characteristics of rammed earth," Construction and Building Materials, vol. 54, pp. 163-169, 2014.

[5] E. Bernat-Maso, L. Gil, and C. Escrig, "Textile-reinforced rammed earth: experimental characterisation of flexural strength and thoughness," Construction and Building Materials, vol. 106, pp. 470-479, 2016.

[6] K. Liu, M. Wang, and Y. Wang, "Seismic retrofitting of rural rammed earth buildings using externally bonded fibers," Construction and Building Materials, vol. 100, pp. 91-101, 2015.

[7] L. Miccoli, U. Müller, and P. Fontana, "Mechanical behavior of earthen materials: a comparison between earth block masonry, rammed earth and cob," Construction and Building Materials, vol. 61, pp. 327-339, 2014.

[8] M. I. Gomes, M. Lopes, and J. Brito, "Seismic resistance of earth construction in Portugal," Engineering Structures, vol. 33, no. 3, pp. 932-941, 2011.

[9] S. T. Maqsood and J. Schwarz, "Analysis of building damage during the 8 October 2005 earthquake in Pakistan," Seismological Research Letters, vol. 79, no. 2, pp. 163-177, 2008.

[10] H. Morris and R. Walker, "Observations of the performance of earth buildings following the February 2011 Christchurch earthquake," Bulletin of the New Zealand Society for Earthquake Engineering, vol. 44, pp. 358-367, 2011.

[11] C. Jayasinghe and N. Kamaladasa, "Compressive strength characteristics of cement stabilized rammed earth walls," Construction and Building Materials, vol. 21, no. 11, pp. 1971-1976, 2007.

[12] A. P. S. Milani and L. C. Labaki, "Physical, mechanical, and thermal performance of cement-stabilized rammed earth-rice husk ash walls," Journal of Materials in Civil Engineering, vol. 24, no. 6, pp. 775-782, 2012.

[13] R. Bahar, M. Benazzoung, and S. Kenai, "Performance of compacted cement stabilized soil," Cement and Concrete Composites, vol. 26, no. 7, pp. 811-820, 2004.
[14] M. Hall and Y. Djerbib, "Rammed earth sample production: context, recommendations and consistency," Construction and Building Materials, vol. 18, no. 4, pp. 281-286, 2004.

[15] K. A. Heathcote, "Durability of earth wall buildings," Construction and Building Materials, vol. 9, no. 3, pp. 185-189, 1995.

[16] A. Perera and C. Jayasinghe, "Strength characteristics and structural design methods for compressed earth block walls," Masonry International, vol. 16, pp. 34-38, 2003.

[17] B. V. V. Reddy and P. P. Kumar, "Structural behavior of storyhigh cement-stabilized rammed-earth walls under compression," Journal of Materials in Civil Engineering, vol. 23, no. 3, pp. 240-247, 2011.

[18] S. Burroughs, "Soil property criteria for rammed earth stabilization," Journal of Materials in Civil Engineering, vol. 20, no. 3, pp. 264-273, 2008.

[19] B. V. V. Reddy and P. P. Kumar, "Cement stabilised rammed earth. Part A: compaction characteristics and physical properties of compacted cement stabilised soils," Materials and Structures, vol. 44, no. 3, pp. 681-693, 2011.

[20] C. Jayasinghe, W. M. C. D. J. Fonseka, and Y. M. Abeygunawardhene, "Load bearing properties of composite masonry constructed with recycled building demolition waste and cement stabilized rammed earth," Construction and Building Materials, vol. 102, pp. 471-477, 2016.

[21] P. Zak, T. Ashour, A. Korjenic, S. Korjenic, and W. Wu, "The influence of natural reinforcement fibers, gypsum and cement on compressive strength of earth bricks materials," Construction and Building Materials, vol. 106, pp. 179-188, 2016.

[22] B. V. V. Reddy and P. P. Kumar, "Embodied energy in cement stabilised rammed earth walls," Energy and Buildings, vol. 42, no. 3, pp. 380-385, 2009.

[23] S. Serrano, C. Barreneche, L. Rincón, D. Boer, and L. F. Cabeza, "Optimization of three new compositions of stabilized rammed earth incorporating PCM: Thermal properties characterization and LCA," Construction and Building Materials, vol. 47, pp. 872-878, 2013.

[24] K. K. G. K. D. Kariyawasam and C. Jayasinghe, "Cement stabilized rammed earth as a sustainable construction material," Construction and Building Materials, vol. 105, pp. 519-527, 2016.

[25] H. R. Hamilton III, J. McBride, and J. Grill, "Cyclic testing of rammed-earth walls containing post-tensioned reinforcement," Earthquake Spectra, vol. 22, no. 4, pp. 937-959, 2006.

[26] D. D. Tripura and R. P. Sharma, "Bond behaviour of bamboo splints in cement-stabilised rammed earth blocks," International Journal of Sustainable Engineering, vol. 7, no. 1, pp. 24-33, 2014.

[27] General Administration of Quality Supervision, Inspection and Quarantine of People's Republic of China, Standard for Soil Test Method, GB/T50123-1999, China Planning Presss, Beijing, China, 1999.

[28] P. Walker, R. Keable, J. Martin, and V. Maniatidis, Rammed Earth: Design and Construction Guidelines, BRE Bookshop, London, UK, 2005.

[29] General Administration of Quality Supervision, Inspection and Quarantine of People's Republic of China, Common Portland Cement, GB175-2007, China Standard Press, Beijing, China, 2007.

[30] R. Park, "Valuation of ductility of structures and structural assemblages from laboratory testing," Bulletin of the New Zealand Society for Earthquake Engineering, vol. 22, pp. 55166, 1989. 


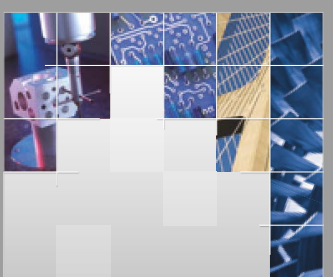

\section{Enfincering}
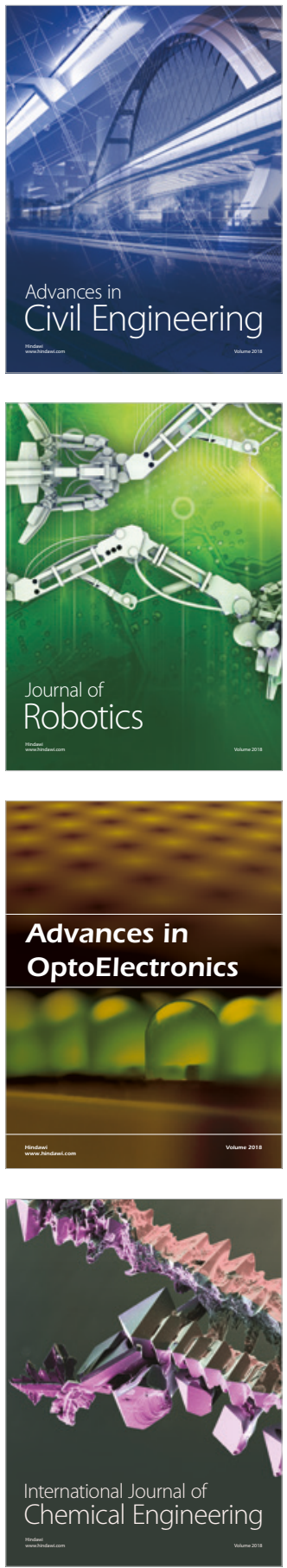

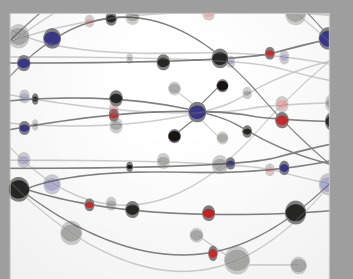

\section{Rotating \\ Machinery}

The Scientific World Journal

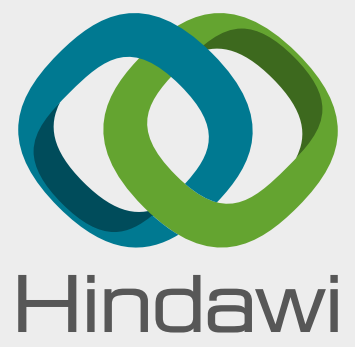

Submit your manuscripts at

www.hindawi.com
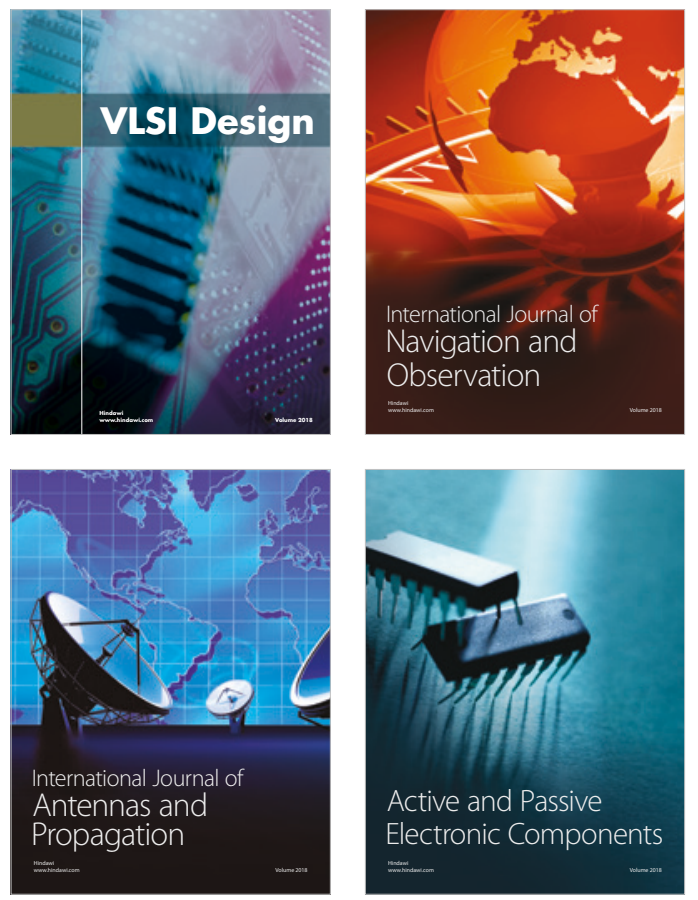
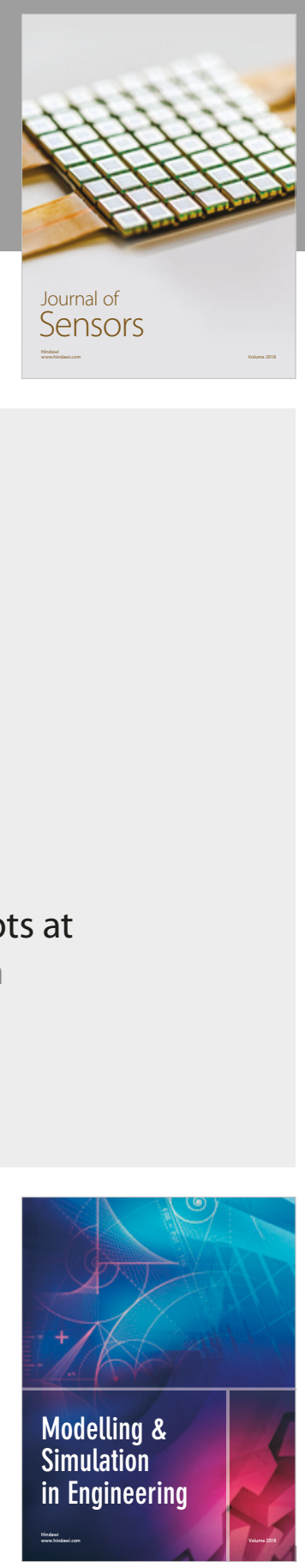

\section{Advances \\ Multimedia}
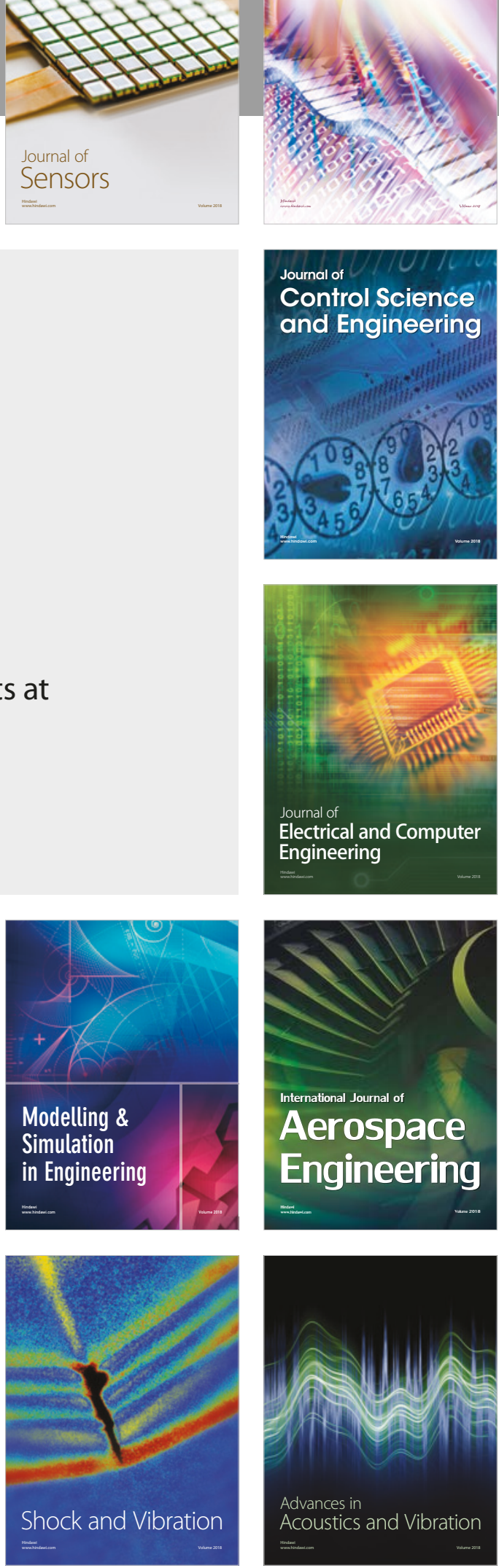